\title{
The role and status of the French language in North Africa
}

\author{
Farid Aitsiselmi and Dawn Marley \\ University of Bradford, University of Surrey
}

\begin{abstract}
Ce chapitre traite du rôle et du statut de la langue française dans le Maghreb d'aujourd'hui en commençant par un rappel rapide du contexte historique pour essayer d'expliquer les origines et les causes des tensions qui existent dans ces pays en ce qui concerne tout ce qui touche les questions de langue et d'identité. Il apparaît clairement que malgré une politique d'arabisation visant à promouvoir la langue arabe et à réduire le rôle de la langue française ou même à l'éliminer complètement de la région, celle-ci continue à occuper une place préponderante dans les trois pays maghrébins. Les conclusions que nous avons pu tirer ne peuvent être que des tentatives de simplification d'une situation complexe qui est en constante évolution et qui change au moment même où nous achevons d'écrire ce chapitre.
\end{abstract}

In this chapter we will examine the role and status of the French language in the Maghreb today, beginning with a brief historical overview to explain the background to this complex issue of language contact. It seems clear that despite an Arabization policy aiming to promote Arabic and reduce the role of French, or even eliminate it completely from the region, the French language continues to play a key role in the three countries of the Maghreb. Any conclusions, however, can only be provisional, as language contact situations are constantly evolving, and even as we complete this chapter new developments will be occurring.

\section{Introduction}

Algeria, Morocco and Tunisia, the former Afrique du nord française, now known in French by the Arabic term, Maghreb, represent an unusual case within Francophone Africa. The term Maghreb was used in Arabic by Medieval Arab geographers to refer to the region: Morocco was known as Al-Maghrib al Aqşa (The Farthest West), Algeria 
as al-Maghrib al Awsat (The Middle/Centre West) and Tunisia as al-Maghrib al Adna (The Nearest West) (Ibn Abd al-Hakam 1922). The term was adopted after Independence to clearly mark the region's affiliation to the Arab world. In 1989, a new political and economic union known as the Union du Maghreb Arabe (Arab Maghreb Union) was created along the lines of the European Union. This entity included Libya and Mauritania, and the five countries together are referred to as Le Grand Maghreb (the Great Maghreb). It was supposed to be the precursor for the creation of a North African Common Market (also referred to as Maghreb Economic Space), but it appears to have done little or nothing to achieve this and has no apparent impact on the everyday life of Maghrebians.

After achieving independence from France, all three countries undertook a policy of Arabization, seeking to eradicate French from public life and restore Arabic to its role as national language. Despite this, French continues to play an important role in a number of domains, and its status is far from that of a mere 'foreign language', which is the only official role it retains. The relationship between the Maghreb and the French language is complex, the result of a long and fraught shared history, particularly in the case of Algeria. An Algerian linguist, Rabah Sebaa (1999: 9) claims that "la langue française occupe en Algérie une situation sans conteste unique au monde" ("the situation of the French language in Algeria is unquestionably unique in the world').

\section{Overview of the language contact situation today}

During the colonial era - 1830-1962 for Algeria, 1881-1956 for Tunisia, and 1912-1956 for Morocco- French was the language of power and prestige, but was limited to the elite. The democratisation of education means that more Maghrebians than ever before have learnt French over the last five decades, and vast improvements in mass communications mean that these people are increasingly exposed to French language and culture through a variety of means previously unavailable - satellite television, recorded material (videos, DVD) and the internet. People in North Africa are aware, as never before, of the language, culture and civilization of France and the rest of the Western world. As Moatassime (2001: 19-20), among others, has noted:

Jamais le Maghreb nia été autant francophonisé que pendant son indépendence, supposée être une période propice à sa (fausse) réarabisation. Mais aussi, jamais le Maghreb, notamment en Algérie, ne s'est autant interrogé sur son identité et son devenir culturel et civilisationnel qu'en ce début du troisième millénaire. ${ }^{1}$

1. 'French has never been as widely spoken in North Africa as it has been since Independence, a period supposedly conducive to rearabisation. At the same time, however, the countries of North Africa, particularly Algeria, have never paid as much attention to their identity and the future of their culture and civilization as they are now at the beginning of the third millennium?. 
Similarly Benrabah (2007b: 203) claims that "Algeria has done more to assist the spread of this language" [our translation] than the colonial authorities did throughout the 132 years of French presence.

However, it is equally true that literacy in Arabic has increased dramatically, and that the same mass technology enables greater exposure to Arabic. Improvements in communications and increased opportunities for travel mean that knowledge of and contact with other Arab countries is much greater than ever before. People in the Maghreb can and do regularly watch Middle Eastern television channels, and are exposed to the language and culture of the Middle East and the Gulf States. New ideas on Arab and Muslim identity can circulate freely, particularly among increasingly educated young people who have no problem understanding the Arabic of these channels.

The indigenous languages of the Maghreb, known to the West as Berber, are also now available on the internet, and cultural production in Berber is gaining a higher profile both in the Maghreb and internationally. Moreover, these languages which have been marginalised for centuries, have in recent years experienced a dramatic change in fortunes. Once seen as the obsolescent languages of isolated and illiterate communities, these languages, collectively now known as Tamazight, are recognized by both Morocco and Algeria as valid languages for education and as worthy of study.

Another element which modern technology has brought in is, of course, the English language. As in most of the world today, English is increasingly evident in a range of domains in North Africa, adding to the variety of language choices available to people. Access to such linguistic and cultural diversity may be seen as enriching, or as adding to linguistic and cultural insecurity. As Skalli (2000: 33) points out, "the increasing connectivity between global/local experiences has given greater visibility to older anxieties about the purity or authenticity of cultural identity". In the Maghreb, as in other postcolonial countries, questions of cultural identity are a continuing matter of anxiety, and the role of the language and culture of the ex-coloniser is a particularly vexed question.

Algeria, Morocco and Tunisia were an important part of the French Empire in the nineteenth and early twentieth centuries, and despite having gained independence some fifty years ago (1956 for Morocco and Tunisia, 1962 for Algeria), they continue to be closely linked in a number of ways, and remain important members of the international French-speaking community, albeit reluctantly, especially in the case of Algeria. Each country has pursued policies of Arabization, destined to remove the French language from public life and replace it with Arabic, yet French continues to be an important language in many areas of life. The proximity of the Maghreb to Metropolitan France, the extremely high numbers of Maghrebian nationals living in France, and the volume of trade and business between France and the countries of the Maghreb all contribute to the continued impact of the French language and culture on the Maghreb.

To put the current situation into context, and to highlight socio-historical similarities between the three countries, we will give a brief historical overview. We will 
focus more closely on Algeria and Morocco, as they share a similar sociolinguistic situation today, with a substantial Tamazight (Berber) speaking population.

\section{Historical background}

Little is known about the earliest civilizations of the Maghreb: the Berbers are considered the indigenous peoples, but all that is known about them comes from outside sources, as they produced no written records of their own existence. It appears though that they have lived as tribes in the mountains and plains of North Africa for millennia, maintaining their distinctive language and culture despite numerous invasions and occupations.

The best-documented period prior to the Arab invasion was the era of Roman occupation, which lasted some five hundred years. The Romans saw this fertile region as a useful source of provisions - wheat, olives and wine - rather than as an area to be colonised. Nevertheless, despite the regular revolts from the Berber tribes, Roman culture and religious thought - both pagan and later Christian - flourished in the Maghreb.

The effects of this Christian occupation however were to be wiped out by the Arab armies which introduced Islam in the seventh century. The Arab invasion of the seventh century, which brought Islam to North Africa, may be seen as the defining moment in the history of the region; the processes of Islamicization and Arabization which began at this time have colored everything that has followed, and continue today to provide the basis of Maghrebian identity for the majority of Maghrebians.

By 670, Arab armies had established a capital in North Africa, Kairouan, and by 710 , the area - together with Spain - was completely under Arab influence. According to Camps (1983: 12), most of the area was probably converted to Islam within two centuries. Arabization, linguistic and cultural, probably occurred relatively early on in the towns, as it became the language of administration and generally of the ruling class, but elsewhere it was a slower process. From the middle of the eleventh century the Arab bedouins of the tribes Beni Hilal and Beni Solaim occupied the plains, pillaged the towns and disrupted social structures, but at the same time, their presence established the Arabic language and way of life in the Maghreb.

Unlike the Maghreb, Spain did not remain under Islamic influence; by 1492 the Catholic Kings had 'reconquered' Spain for the Church, and then turned their attention to North Africa. The people of Algiers asked the Ottomans to protect them from the Spanish, at which point the history of the Maghreb was divided into two quite separate courses: the Central and Eastern areas - Algeria and Tunisia - came under the influence of the Ottoman Empire, where they would remain for the next three centuries, until the French gained power. Meanwhile, the Western Maghreb, Morocco, despite incursions and some occupations by the Portuguese and Spanish, continued as an independent and increasingly isolated state, until the arrival of the French in the early twentieth century. 
Despite this division, Islam acted as a uniting force across the region. The Moroccan historian Laroui (1975: 63-64) summarises the Ottoman era as one in which the Maghreb, despite the different regimes in place, became in some ways the united region it is today. He notes, however, that it was also united in what it lacked: a strong national army and a sound economy, and it is this common lack, Laroui argues, which explains why all three countries were colonized.

In 1830, the Maghreb as a whole was weak, with internal divisions in each country and there was little resistance to the French invasion. In a matter of weeks, the Ottomans were gone and the French were in control of Algeria. However, the problem of administering the country was one that would take the next half century, and ultimately was never to be resolved. Despite the initial conquest, the French met with resistance to their rule, but by the end of the nineteenth century, "the once relatively prosperous Muslim population of Algeria had been rendered second-class and dispossessed" (Stone 1997: 32). The French historian Peyrouton (1966: 201) was to write that by the turn of the twentieth century France saw Algeria as "sa fille délection, le reflet de son propre génie" ('her chosen daughter, reflecting her own genius').

The French did not invade Tunisia and Morocco, setting up protectorates instead, in 1881 in Tunisia and 1912 in Morocco, helping weak rulers to crush rebellion and modernise their countries, and effectively running them until their independence in 1956. Relations between the French and these two 'protected' nations were far more cordial than between France and Algeria, and independence was achieved without bloodshed, although nationalist movements had a long struggle before achieving their goals. In Algeria, however, the war of independence began with the insurrection of November 1954, under a single National Liberation Front (FLN) and did not end until 1962.

\subsection{The post-colonial era}

The history of independent Algeria can be divided into three periods. The first corresponds to the presidency of Ahmed Ben Bella (1962-1965) who was overthrown in a bloodless military coup by Houari Boumediene (1965-1978). During his thirteen years in power, Boumediene created a strong centralized government, based on a oneparty system (FLN - Front de Libération Nationale). When he died in 1978, rapid progress had also been achieved in professional training, making possible the Algerianisation of managerial personnel and the Arabisation of the education system.

The second period, from 1979 to 1992, corresponds to the presidency of Chadli Bendjedid, who began a policy of liberalisation of the regime. This period saw the emergence of numerous political associations supported by a flourishing press as well as independent publishing houses. It also witnessed the emergence of Islamism as an ideological alternative to the single party system. During this era, there were also two violent riots. The first erupted in March 1980 in the Berber region of Kabylia against Arabisation and in favor of recognition of Berber as a national language. The second occurred in October 1988 in Algiers and other main cities, in support of democracy, 
leaving between 200 and 500 dead, and leading to 355 arrests (Stone 1997: 64). These events mark a turning point in Algerian political life, as they signal the "beginning of the Islamist bid for power" (Heristchi 2004: 116). The first free elections in December 1991 produced a landslide victory for the FIS (Front islamique du salut 'Islamic Salvation Front'), which in turn provoked the cancellation of the elections by the army, and the resignation of the president.

The third period, from 1992 to the present, corresponds to the period of terror unleashed by this breakdown in the democratic process and the various attempts at 'national reconciliation'. It revealed a society filled with rivalries and contradictions: "Islamist/ secularist, arabophone/ francophone, civilian/ army, Berber/ Arab, socialist/ liberal, patriarchal men/ 'liberated' women” (Naylor 2000: 193). Roberts (2003: 20) identifies five main currents of opinion: "the left, the Arabists, the Berberists, the feminists and the Islamists". This political instability seems to have reached a relative end with the election of Bouteflika in 1999 and his re-election in 2004.

In some ways, Tunisia is the country that has most successfully made the transition from protectorate to fully-fledged nation state. Politically, it has been stable, with Habib Bourguiba staying in power until his prime minister, Zine el-Abidine Ben Ali, took over in a 'coup détat médical' in 1987, declaring that Bourguiba was no longer fit to govern, on the grounds of senility. Bourguiba was committed to transforming Tunisia into a modern country, and had a very secular outlook, firmly opposed to Islamic fundamentalism. He introduced many reforms, particularly in areas such as women's emancipation, making Tunisia one of the most secular of Muslim countries. Ben Ali also takes a firm line with fundamentalists, and is seen as a modernizer.

However, he too has been criticized for his authoritarian style, and the $99.9 \%$ results in elections. Tunisia is generally better economically developed than the other two countries and also has a higher standard of living - Tunisia was placed 87 th in the United Nations' HDI (Human Development Index) report of 2007, compared to Algeria and Morocco, which came in 102nd and 123rd position respectively (http://hdr. undp.org/hdr2006/statistics/). Tunisia is now a predominantly urban nation, with an increasingly well educated population.

Like Tunisia, Morocco has been politically stable for most of the past half century. The first king of the independent state, Mohammed V, died in 1961, to be succeeded by his son, Hassan II. After surviving military coups in the 1970s, Hassan II ruled with a firm hand, and was criticized by human rights groups for his suppression of opposition within Morocco. In the final years of his reign, he did allow parliamentary democracy to develop, and promised greater freedoms. At his death in 1999, his son Mohammed VI took over, pledging to move the country towards greater political pluralism and economic liberalism.

Mohammed VI has not been totally successful in his attempts to bring about greater transparency in government and greater justice in society, but in many respects the country has modernised during his reign. One significant issue which was finally addressed in 2003 was the long awaited reform of the Moudawana, the family code 
which kept women in a subservient position. Moroccan women now enjoy far greater rights than ever before, although they are still no better off than Tunisian women. Since 2000, educational reform has seen rapid improvement in numbers of children in school, but illiteracy rates remain high, and the gulf between rich and poor, as well as town and country, remains wide.

Today all three countries find themselves facing difficult cultural issues: despite having opted for Arabization and closer identification with the Arab world, some people in the region are more likely to aspire to adopt a European lifestyle; Morocco and Tunisia have been trying for years to join the European Union. In recent years, the issue of Islamic fundamentalism has become more acute, and the tensions which arise from trying to reconcile this tendency with the modernising tendencies are great. The majority Muslim population and the professed Islamic nature of the state have been no protection from terrorist attacks, which occurred again in Morocco and Algeria in April 2007.

We now move on to an overview of the language contact situation which has emerged over the centuries in the Maghreb, as different languages have found themselves not only in contact, but also in competition.

\section{Language competition}

The indigenous peoples of the Maghreb, the Berbers, resisted shifting to Latin or the language of any other invader until the seventh century, when the Arabs introduced Arabic, the language of Divine revelation. Although the Berbers did not rapidly shift to Arabic - even today there are still non-Arabic speaking Berbers - a diglossic situation evolved in which Arabic was the $\mathrm{H}$ language for religious, administrative and other formal functions. Over the course of several centuries, bilingualism also became the norm in towns, and much later in rural areas, as Arab settlers mixed with the indigenous population. Turkish, on the other hand, despite centuries of Ottoman rule in Algeria and Tunisia, seems to have had as little linguistic influence as Latin. This can be partly explained by the fact that there was never a large Turkish population in the region, nor any attempt to integrate it culturally. Moreover, the Turks, as Muslims themselves, would revere Arabic, and would not seek to undermine it. The French, on the other hand, did seek to assimilate Algeria culturally and linguistically, and to create a Francophone elite in the other two countries. The result of these policies can be described as a situation of triglossia, which still exists today, where French, like Standard Arabic, is the $\mathrm{H}$ language. Although French is rarely spoken as a mother tongue, its acquisition is regarded as valuable, and its use is widespread in various domains. Two other European languages also need to be taken into account, Spanish in Morocco, where it was once widely spoken, and English, which across the region is offering increasing competition to French. We will now look at each of these languages in turn. 
The term 'Berber' actually covers a continuum of related but not always mutually comprehensible languages, belonging to the Hamito-Semitic family, which is distantly related to Arabic and other Semitic languages. Berbers themselves use another term to refer to the Berber community, Imazighen (singular, Amazigh), with the derivative Tamazight for the language, to encompass all varieties, not just the one in Morocco (Middle Atlas) traditionally called Tamazight. This term is used in the modern Berber cultural movement which attempts to unite the different tribes and varieties, in their struggle for cultural recognition and survival. Imazighen live not only in the Maghreb but across a much wider area of North-West Africa, extending across Libya and down into the Sahara.

These languages, often referred to as 'dialects' or even 'patois', are still widely used in Algeria and Morocco, perhaps by as much as $40 \%$ of the population Boukous (1995: 10). In Tunisia, however, probably less than $1 \%$ of the population is Berber-speaking. Estimates differ wildly, however, and in the absence of census data on the subject, it is impossible to know true numbers.

There is little documentary evidence of the presence of these languages in the Maghreb, since the script, Tifinagh, which was used in other parts of the Tamazight zone, has apparently never been known there. In the Maghreb these languages have survived almost exclusively in spoken form, their cultural history being handed down orally over the centuries. This lack of a written form contributed to the development of a diglossic situation, as it meant that Arabic became the obvious language of administration and education, and therefore the $\mathrm{H}$ language, whilst Berber languages were relegated to the $\mathrm{L}$ domains.

This example of diglossia came into existence alongside another, 'purer' form, indeed, one of Ferguson's original (1959) examples, involving two varieties of Arabic: dialectal and classical. It must be mentioned, in passing, that the term 'Arabic' refers to a continuum of language ranging from the Classical language of the Koran, through 'Modern Standard Arabic' to regional and national dialects which are not all mutually comprehensible. All these varieties are related, but there is a widespread belief among Arabic-speakers that only 'classical' Arabic, the language of the Koran, and the modern written form which is directly related to it, can be considered 'real' Arabic; the dialects which people speak, and which therefore change with time to reflect changes in society and influences from other societies and languages, are regarded as deformations of the true language, and thus inherently inferior. However, as Mouhssine (1995: 52) points out, if the 'classical' language has succeeded in remaining 'pure', or untouched by change over the centuries, it is simply because the 'dialects' have changed, in order to cope with the reality of daily life.

A diglossic situation has thus arisen because the written language, used for religious purposes and, to a lesser extent, for education and administration, has remained relatively unchanged, whilst the dialects, widely used for everyday purposes, have evolved very differently. For centuries now, dialectal Arabic has functioned as an L language, being used for all types of speech in everyday life, but having no written form; 
classical Arabic holds all the $\mathrm{H}$ functions - religion, administration, education and media. The dialects are acquired as mother tongues, whilst the classical language is only acquired via schools and is only used in its written form, or in a liturgical function.

In addition to these two forms of diglossia, Tamazight-Arabic bilingualism inevitably developed across the region, as Arabs and Berbers interacted, traded, intermarried and lived together. Due to the higher prestige of Arabic, there has been a tendency to shift to Arabic, but bilingualism persists, and although there may not be many monolingual Tamazight speakers any more, there are still large numbers who are bilingual.

Despite the prestige and practical value of Arabic, European languages have become important in the Maghreb since the nineteenth century, notably Spanish and French. Spanish has a longstanding relationship with the Maghreb, and Spain tried to occupy parts of Morocco from the fifteenth century onwards. Spanish only really had a significant impact on Morocco, and even then only in the North, during the late nineteenth century and the first half of the twentieth century. There was considerable Spanish immigration to both Morocco and Algeria in the 1830s and 1840s, as a result of a long lasting drought in southeastern Spain, and the political upheavals of the nineteenth century (Sayahi 2004: 38). Today, however, only two Spanish enclaves remain, Ceuta and Melilla, on the Mediterranean coast of Morocco, and the Spanish language is generally in decline, although the modernisation of Spain since the end of the Franco era, and its geographical proximity make it very attractive to Moroccans wishing to emigrate. This makes Spanish an attractive and useful language to people in the North of Morocco, if not elsewhere in the region.

French, on the other hand, has had a deep influence across the region, even if there has only been a French presence since 1830. The French belief in the mission civilisatrice 'civilizing mission' of their language led to a desire to create an elite who would think and act like them, whilst keeping the mass of the population illiterate.

The vast majority of the population in all three countries remained illiterate, since this suited the French and the local elites, but for those who aspired to power, French replaced Arabic. They thus turned an already diglossic situation into a triglossic one for a small percentage of the population for which French became a new $\mathrm{H}$ language. It could not supplant Arabic in terms of religious prestige, but it quickly became the $\mathrm{H}$ language for the administration, education and large areas of the economy and business. The rapid success of French was partly a simple case of French being the language of the most powerful group in society, but it was helped by the declining state of existing infrastructures, and the stagnant nature of standard Arabic.

The economy and the political system, as noted earlier, were weak, and indeed this had been the justification for French intervention in Tunisia and Morocco. The French therefore imposed their system and operated in their language. In Algeria, they simply took over from the previous colonisers and again imposed their own system and language.

The education system was also in decline, although in Algeria the literacy rate among men was estimated at $40-50 \%$ of the population (Wardhaugh 1987: 186). As 
part of their policy of assimilation and their administrative tradition of standardization, the French destroyed the existing education system in Algeria and imposed their own, in which French was the sole medium of instruction. The majority of the Algerian population refused to send their children to French schools, through fear that it would not only lead their children to adopt French culture but, worse still, to adopt Christianity (Benrabah 1999: 49). Their fears were confirmed by the important role played in education by the Jesuit missionaries (Pères Blancs and Sours Blanches). Although this attitude was to change later, particularly after the Second World War, when many Algerians began to recognize the value of knowing the language of the coloniser and to demand better education in French, by the end of the colonial era, scarcely 15\% of the population knew French.

In Tunisia and Morocco, different techniques were employed and the cultural trauma was far less severe than that experienced in Algeria. In both countries, the teaching of French predates the establishment of the Protectorate, where French schools were seen as "un moyen de pénétration et d'assistance, un organe d'apprivoisement et de rapprochement" ('a way of establishing a presence, a tool for 'taming' people and bringing them closer') (1916, quoted in Seux 1997: 98). In Tunisia, the bilingual system was modelled on the Collège al-Sadiki, which produced the Westernized middle class nationalists represented by Bourguiba. In both countries, on the eve of Independence, only about $10 \%$ of the indigenous population was in education. This meant that the elite, who were in power, tended to be bilingual in French and Arabic, and thus French was seen as a distinct asset in post-colonial society.

Although we have been using the generic term French to refer to the colonial language, it should not be assumed that French is widely spoken with a high degree of proficiency. Sociolinguists such as Derradji (2005) and Benzakour $(2004,2007)$ refer to several levels of French in the Maghreb, using Bickerton's (1981) concept of a continuum. Thus there is the acrolect, or standard French, at one end of the continuum, and the basilect, or least prestigious variety at the other. The acrolect is used in formal situation by the elite and more generally by people with a high degree of education. The basilect is the style of French used by those Benzakour calls the "petit peuple" people with a low level of education, who have learnt French informally through contact with French speakers, for example in their roles as domestic staff, unofficial tour guides and so on (Benzakour 2007: 52). Between these two poles there is an intermediate variety - or several varieties - known as the mesolect. Benzakour sees this variety as the most widespread in Morocco at least, describing it as the variety which has been adopted by Moroccans as their own: it borrows heavily from local languages, uses neologisms and, whilst it lacks the prestige of Standard French, it is valuable as a marker of identity, as it is essentially 'Moroccan French'. 


\section{Language planning in the postcolonial Maghreb}

Language planning in the Maghreb is complicated by a range of ambivalent attitudes towards both French and Arabic. Boukous (1999a: 61) summarizes the situation in Morocco as follows:

bien que l'arabisation constitue le fondement de la PL [politique linguistique], un compromis pragmatique est établi entre la francophonie et l'arabisation, c'est-à-dire entre les séquelles linguistiques et culturelles de la période coloniale et la volonté d'indépendance culturelle et linguistique qui caractérise la période postcoloniale. Cette situation reflète les ambivalences d'une PL qui tergiverse entre les pesanteurs de l'authenticité et les aspirations à la modernité, ce en quoi elle est plus symbolique et idéologique que rationnelle et efficiente. ${ }^{2}$

Arabization was seen as the cultural counterpart to political independence, and therefore the governments of the newly independent states took urgent measures to replace French with Arabic as the language of education, administration and public life in general. At first glance, this would appear to be a logical language planning initiative, assured of success: Arabic had been the $\mathrm{H}$ language for centuries, and the mass of the population spoke a variety of Arabic. However, there are a number of factors which go some way towards explaining why it has not fully succeeded. They can be summarized as follows: the Arabic imposed as the new official language - MSA - is not the mother tongue of any group in society, even the ruling class; there was no 'communication problem' to be solved, as the majority of the population speaks dialectal Arabic; the motivation to discard French was weak, as French was perceived as useful in gaining access to a wide range of material in the modern world. Moreover, French is generally perceived as a modern language, whereas Arabic is not, and in fact is habitually associated with tradition and the pre-colonial past.

Finally, there is one major factor which cannot be ignored in the modern world: media and communications. Although all three states use their own television channels to promote their linguistic policy, they no longer control the media. Satellite television, improved telecommunications and the rapid growth of the Internet mean that even the poorest Maghrebians are regularly exposed to other languages and viewpoints from outside the Maghreb. This improvement in communications has helped the Amazigh Cultural Movement, and thus slowed down the disappearance of these languages; it has also given greater incentives to learn French and, increasingly, English, in order to access the materials available in these languages.

2. Although the language policy is based on Arabisation, there is a pragmatic compromise between the use of French and Arabization, that is to say between the linguistic and cultural consequences of the colonial era and the desire for cultural and linguistic independence typical of the postcolonial era. This situation reflects the ambivalence of a language policy which hesitates between the weight of 'authenticity' and aspirations to modernity, which makes it more symbolic and ideological than rational and efficient. 
In wilful ignorance of many of these factors, the newly independent governments of the Maghreb pursued a policy of Arabization. Before looking at how they implemented the policy, we will look briefly at the ideology behind it.

\subsection{The ideology of Arabization}

Since the seventh century, the countries of the Maghreb have been Muslim, and the restitution of Arabic was seen a means of asserting their Arab-Islamic nature. Classical (Koranic) Arabic had been an important symbol for all the nationalist movements prior to independence, and it was widely felt that Arabic was the most appropriate official language of an Arab-Islamic state. Arabization was seen as the best way of restoring the 'authentic' identity of nations which had been 'depersonalized' by colonialism, and as a uniting force within each state. The countries of the Maghreb have, for over four decades, been trying to achieve national unity via linguistic unity, wilfully ignoring the fact that such unity is not 'natural' and that the 'authenticity' ascribed to the national language has never been the only element in national identity. This is particularly the case in Algeria and Morocco, where large sections of the population had never been Arabic speakers at all, and nowhere has the Arabic of Arabization ever been a mother tongue.

Despite having no native speakers, Classical Arabic has proved to be "un élément indispensable d'une construction nationale" ('an indispensable tool for nation building') (Grandguillaume 1983: 34), largely because of the high status it enjoys in an overwhelmingly Muslim society. It does act as a unifying force because of its symbolic status as the language of divine revelation. It also symbolizes self-affirmation against (non-Muslim) foreigners, particularly the French, and national pride, since it is seen, perhaps oddly, as the 'natural' language of the Maghreb.

Some claim that there is another, largely unspoken, aspect to this ideology: the eventual elimination of those languages which might more reasonably be called 'natural', that is Tamazight. This aspect of Arabization has been raised in recent years by linguists such as Boukous (1999a, b) and Benrabah (1999), who accuse the governments of Morocco and Algeria respectively of seeking to eliminate Tamazight and even, in the long term, dialectal Arabic. They lament the fact that their governments should deny the reality of cultural and linguistic diversity which is the great richness of the Maghreb, preferring instead to promote what they see as a dead language, using it as a symbol of past greatness and of a past 'authentic' identity.

These same critics also suggest that the elites have promoted Arabization, cynically, as a means of maintaining power, knowing that French would continue to be necessary to social and economic success, and thus continuing to educate their own children bilingually (Boukous 1999: 53). Benrabah (1999: 160) goes even further in his criticism of Arabization in Algeria, claiming that it has had the same objective as Orwell's 'Newspeak': to deprive the Algerian people of their language and to impose a 
language in which they would be unable to express themselves or even to think in a critical way.

Despite the indifferent success of this policy, all indicators suggest that the vast majority of Maghrebians believe that Arabization is ideologically desirable, and support it in theory, even if they recognize the practical difficulties of implementing it. Nevertheless, Benrabah (2007b: 207) suggests that "Algeria's elites have failed to promote Literary Arabic as an attractive 'product' to which a high 'value' would be assigned on the Algerian 'linguistic market"'. In other words, Algerians are not convinced that using Classical Arabic would provide them with potential benefits such as social mobility or better of socio-economic life. As we will now see, the practice of Arabization continues to be problematic.

\subsection{The practice of Arabization}

Although all three countries decided to implement Arabization immediately, implementation of the policy has been sporadic everywhere, due to a variety of internal and external factors. The major areas affected by Arabization are the education system, the administration and the environment, this last being a rather vast area that could equally well be called 'public life'. It is the first area, education, which has received the most attention, as it is relatively easy to pass laws and implement them in this area. Even in this domain, however, Arabization has not always proceeded smoothly.

In Algeria, the first step towards Arabization was the introduction, in 1962, of seven hours a week of Arabic teaching in primary schools. This was increased to 10 in 1964 when it was also decided that the first year of primary education should be entirely in Arabic. This proved difficult to implement due to the acute lack of adequate teachers of Arabic. Any Algerian with a basic knowledge of Arabic could be called a moniteur ('instructor') and allowed to teach in schools, but even so the government was forced to recruit a thousand Egyptian teachers in order to achieve its aims. Although Ben Bella declared that Arabization did not mean Islamicization, in 1963 Islam was decreed the state religion, and his famous declaration "Nous sommes Arabes" ("we are Arabs') showed clearly that for him Algeria's identity would be firmly, and exclusively, bound up with its Arab and Muslim dimensions (Benrabah 1999: 79).

In 1965, Houari Boumediène seized power and began to implement much widerranging measures to promote Arabization. His clear aim was to eradicate French and replace it with Koranic Arabic. His Education Minister, Ahmed Taleb Ibrahimi, saw the Arabization of the education system as the way to:

anéantir ce mélange déléments de cultures disparates, et souvent contradictoires, héritées des époques de décadence et de la période coloniale, de lui substituer une 
culture nationale unifiée, liée intimement à notre passé et à notre civilisation araboislamique (Taleb Ibrahimi, cited in Benrabah 1999: 95). ${ }^{3}$

Over the next two decades the school system was Arabized in fits and starts, and the last bilingual baccalauréat was organized in 1988. Despite this, the debate over the use of French in higher education is not yet over in Algeria.

Arabization in Tunisia has tended to be a less emotive affair, partly because Tunisia never lost its status as a nation, which meant that Tunisians did not feel quite the same need as Algerians to find their own authentic identity. It was also in large part due to Habib Bourguiba, the first president of independent Tunisia, who was himself bilingual and a known francophile, being one of the founding fathers of the modern francophone movement. However, he too was very much in favor of Arabization, as he stated in an early speech to the elite Collège Es-Sadiqi (where he, like most of the elite of his generation, had received a bilingual education):

L'enseignement dans les écoles secondaires sera orienté vers l'arabisation et l'emploi de la langue arabe, de sorte que celle-ci soit la langue d'enseignement de toutes les matières, sauf si la nécessité et les circonstances imposent - provisoirement - l'emploi de la langue française pour tirer profit des possibilités qui soffrent à nous, en attendant de préparer les écoles normales et les cadres nécessaires pour l'enseignement en langue arabe de toutes les matières. (cited in Grandguillaume 1983: 63)

As in Algeria, the Arabization of the education system has been fitful, and the whole process has been marked by ongoing debates between the proponents of total Arabization, and those in favor of bilingual education. The Arabization of the school system was completed by the end of the 1980s. This seems to have coincided with, or contributed to, a renewed interest in, and desire for, the French language. Although Tunisia is officially Arabized, unofficially it is very definitely bilingual, and continues to see itself as a key player in the francophone world. Tunisia continues to see, at an official level, the benefits of maintaining linguistic and cultural links with France.

In Morocco too, the Arabization of the education system and other areas has been marked by frequent hesitations and compromises, with the result that today there is still a de facto bilingualism in many theoretically arabized areas. Having given Arabic official status, the government proceeded to create a legislative framework to support this status. However, the numerous decisions to implement Arabization at various levels have almost invariably been followed by decisions to continue to use Arabic-French bilingualism.

3. 'Teaching in secondary schools will be geared towards Arabisation and the use of Arabic, so that this language can be the medium of instruction for all subjects, apart from when needs and circumstances dictate - temporarily - the use of French in order to take advantage of possibilities available, whilst waiting for teacher training institutes and the necessary personnel to enable Arabic to be used as the language of instruction for all subjects'. 
There have always been two tendencies in the application of language policy: the desire for a rapid Arabization, favored by the Istiqlal Party, and a preference for maintaining French in science subjects and moving more cautiously. In 1978, for example, before a parliamentary commission, the king declared "Nous sommes pour l'arabisation. Mais si elle est un devoir, le bilinguisme est une nécessité", 'we are in favor of Arabization. However, if Arabization is a duty, bilingualism is a necessity' (Quoted in Mouhssine 1995: 49), and a decade later was quoted in a national newspaper (L'Opinion, 1988) as saying:

Je considère que ceux qui ne cessent d'appeler à l'arabisation ne sont pas encore libérés car leur esprit est encore bourré d'infériorité [...] Le fait que je parle la langue française - et j’aurais aimé parler d'autres langues - ne signifie pas que je suis encore sous le Protectorat des Français. ${ }^{4}$

In addition to the legislative framework, a number of organizations were set up to assist in the implementation of language policy, and numerous ad hoc commissions were created within the Ministry of Education to deal with the pedagogic implications of Arabization. The result of all this activity is that by 1990, primary and secondary education were fully Arabized, but science and technology were still taught in French at the university level. In administration, technical departments still functioned in French, whilst legal, social and cultural departments used Arabic as the working language.

Nevertheless, the language issue did not go away, and in the Charte nationale d'éducation et de formation ('National Charter for education and training'), the document setting out the framework for a decade of educational reform, the language issue is addressed among the fondements constants ('foundations') on the first page. The language policy set out in this document stresses the importance of Arabic as the national language, but also acknowledges the need to use 'other' languages where necessary, particularly in science and technology. Whilst the Charte does not advocate a 'francisation' of the system, it does effectively acknowledge that French may be a more useful tool for the teaching of science and technology. Clearly to renounce the Arabization of science teaching at this stage would be unthinkable; the charter therefore emphasizes that over the next ten years Arabic will become a suitable language for the teaching of science, and recognizes that in the meantime another language, logically French, is better suited to the task. It thus succeeds in remaining true to the principle of Arabization, whilst acknowledging that for the immediate future, bilingualism is a necessity.

To conclude this brief overview of Arabization, these words by Cheddadi, referring to Morocco, could be applied to the whole of the Maghreb:

Le souci identitaire imposa le choix de l'arabe comme langue nationale. Par chance, ce choix est sans aucun doute le meilleur possible. [...] Mais tout d'abord, il nallait

4. 'I consider that those who are constantly calling for Arabization are not yet independent, because they are still suffering from an inferiority complex [...] the fact that I speak French - and I wish I could speak other languages - does not mean I am still under the French Protectorate. 
nullement de soi. Il fallait le justifier clairement par rapport aux autres langues parlées au [Maghreb] et définir le statut de celles-ci. Ensuite, sa mise en cuvre posait d'énormes problèmes qu'il fallait exposer aussi clairement et exhaustivement que possible. Enfin, il fallait déterminer un plan de développement et dégager les moyens humains et financiers nécessaires à sa réalisation. Malheureusement, la plupart de ces questions furent éludées ou traitées superficiellement et sans esprit de suite. (Cheddadi 2003: 93-94) $^{5}$

Standard Arabic in a sense was the best, if not the only, choice of national language. However, the way in which this language policy has been applied has clearly not been satisfactory in any of the countries. As in all multilingual settings, opting for one national and official language is bound to be problematic, and it would appear that the governments of the Maghreb did not foresee any of the problems, and have been unable to cope with them. Thus after half a century, the national language question is fraught with problems, practical and ideological, most of which show no signs of abating in the immediate future. As a result, the French language, which governments had expected to eradicate in Maghrebian public life, continues to have a very particular role and status in the post-colonial Maghreb, as we shall now see.

\section{The current role and status of French}

Although it has lost the status it had during the colonial era, French has gained massively in numbers of speakers, since education in the postcolonial age is far more widespread, and French has remained an important element of the education system across the Maghreb. Despite half a century of Arabization, the French language retains a strong physical presence in the region. French appears, together with Arabic, on street names in town centers, and directions signs both in towns and on major roads outside towns. Many shops and cafes, banks and other businesses have their signs written in both French and Arabic, as do hospitals, schools and local and national government buildings. Official documents such as bills for utilities and taxes are bilingual, as are doctors' prescriptions and most medicines, postage stamps, coins and bank notes. French can be heard on radio and television, even on the official government channels, and French language publications are as common as Arabic in bookshops and

5. 'The identity issue meant that Arabic was the only option as national language. As it happened, this choice is undoubtedly the best possible [...] However, this was not a foregone conclusion. This choice had to be justified and the other languages spoken in the Maghreb had to have their status defined too. Moreover, putting this choice into practice was fraught with problems, which needed to be clearly and comprehensively recognized and dealt with. Furthermore, a proper plan should have been thought out and the means to carry it out, both financial and in terms of human resources, should have been made available. Unfortunately most of these issues were evaded or were treated superficially without being adequately thought through'. 
newspaper kiosks. In Algeria, more than half the books published by the various private and public publishers are written in French (Kadi 2004, quoted in Benrabah 2007b: 209). Moreover, as memories of the colonial era fade, attitudes towards French and its use are also changing, as demonstrated by the fact that in Algeria President Bouteflika and Prime Minister Ouyahia recently delivered official speeches and press conferences in French (Le Monde, 18 April 2005: 6)

In the early days after Independence there were three major schools of thought regarding the role of French in Morocco (Benzakour, Gaade \& Queffélec 2000: 59): the technocratic modernist idea that maintaining French was essential for Morocco's economic, social and cultural development; the traditionalist, Arab-Islamic viewpoint, espoused by Istiqlal, that maintaining French would 'denationalize' the country; the 'anthropological' idea that a balance should be sought, with French remaining as primary language in some areas, and Arabic taking over in others. As time has moved on, and Arabization has occurred, these views have developed. Most notably the pro-Arabization stance has moved closer to the 'anthropological' idea, accepting that the presence of French in some domains does not threaten the primordial position of Arabic.

These three tendencies can be identified in Algeria too. The 'bilingual group' believes that Arabization is a slow, progressive process during which Arabic-French bilingualism must be maintained in order to gain access to modern technology. The 'multilingual group' calls for the recognition and promotion on an equal footing of all the languages used by Algerians, that is, Algerian Arabic, Tamazight and French (Benrabah 1999: 347). The third tendency is a 'total Arabization group' which stresses that the major priority of the country is to re-establish Arabic, the sole national and official language, as the expression of the Arabic and Islamic identity of the Algerian people (Assous 1985 :123; Mansouri 1991: 35).

In the early twenty-first century, with the Arabization of education and administration largely completed, French is not resented as the language of colonial oppression, but seen by many, if not most, as an asset. French remains essentially an asset of the elites, rather than the majority, but even so "il reste valorisé dans l'imaginaire marocain et l'engouement qu'il suscite trouve sa source première dans les enjeux qu'il représente" 6 (Benzakour et al. 2000: 79). In Algeria, an education in French is seen as an atout précieux ('valuable asset') by the parents who pay for their children to attend the three hundred private schools which offer this (Le Monde April 18, 2005: 6)

Numerous studies over the last quarter of a century have indicated that French continues to be viewed very favorably by Moroccans, regardless of their own ability in this language. In his study of Arabic-French bilinguals in Morocco over 20 years ago, Bentahila (1983: 160) made the following comment:

Moroccan bilinguals consider their knowledge of French to be a considerable asset, which offers them greater knowledge, wider experience, access to the Western

6. 'It continues to be highly valued by Moroccans, and the passion it arouses can be explained primarily by the stakes that it represents'. 
world and to an endless supply of material which they would not otherwise be able to reach.

In 2007, with the technological advances which have brought satellite television and the internet into the most remote corners of the Maghreb, this is more true than ever, and it is not just the bilingually educated elite who see the advantages of knowing French.

The enjeux ('stakes') represented by French are both concrete and ideological, with the result that Maghrebians may wish to learn French for both 'instrumental' and 'integrative' motives. On a practical level, French is viewed as the key to social and economic success, whether at home or abroad. There is a clearly perceived link between speaking French and achieving success: people in power, be it in politics, the army, business, banking, public and private companies, always have a good command of French. Similarly, anyone engaged in scientific research, and indeed many other branches of university research, uses French, as do the liberal professions and most middle ranking executives. In short, French is the key to the modern job market even in the Maghreb, and obviously is essential for anyone hoping to find work outside the Maghreb, since traditionally 'abroad' has meant France or a French-speaking country.

In addition to these practical benefits, the French language is widely seen as a means of access to French culture, which in turn is representative of Western culture. Learning French is therefore seen not only as a way of securing a better job, but also as the means of participating in a more liberal, emancipated lifestyle, and the consumer society. Secondly, it is the means of access to the world of modern science and technology. French is simply a synonym for modernity for many Maghrebians, and speaking French is a means of improving one's social standing.

Some studies, even in the 1990s (Bentahila 1983; Elbiad 1991; Mouhssine 1995) have suggested a lingering resentment of the language, but this is usually outweighed by a desire to identify with the values it represents. Mouhssine (1995: 53), for example, found the attitudes of students at the University of Fez to be "imprégnées d'une forte ambivalence" ('riddled with ambivalence'): they rejected French as a cultural value, but wanted to maintain it as a tool for communication. Boukous (1999) found that many Moroccans were profoundly disillusioned by Arabization, and were firmly in favor of a bilingual education for themselves and their children. Moreover, attitudes towards French continue to be positive, among young people who have grown up in an Arabized system at least as much as among those who experienced the bilingual system of the 1960s and 1970s. In a recent study among school children in Khouribga (Marley 2004), the overwhelming majority of informants claimed to like learning French and believe that it is important for Moroccans to learn it, that it is useful for working in Morocco, and that it offers various advantages to Moroccans. An earlier study among a cross-section of Moroccan society (Marley 2000), indicated that most Moroccans, even those who have had no formal education, see French as a normal part of everyday life, and are favorably disposed towards it. 
Similarly, a recent survey showed that Algerians have a positive attitude towards French and that they do not particularly value monolingualism since "literary Arabic alone does not ensure social mobility, which is considered possible mainly through the mastery of Arabic-French bilingualism" (Benrabah 2007a: 243). Moreover, the same survey showed that in spite of the high prestige that the English language currently holds, the attitudes of the respondents were favorable to French when they were offered English as an alternative to French as they "seem to reject policies that seek to displace French in favor of English" (Benrabah 2007a: 245).

The status of French in the Maghreb today is thus rather ambiguous. Whilst it may be seen as inappropriate for people in some social circles to use French, among many educated and professional people, French is almost as natural as Arabic, and many others aspire to this.

\section{Code-switching and linguistic hybridity}

Language contacts in multilingual societies are the source of a number of well-known linguistic phenomena such as borrowing or loan words (usually single-item terms but also phrases) from one language into the other as well as code mixing, the alternate use of two or more languages in a single utterance (intrasentential) or code switching, the use of two languages within a conversation (intersentential) (Myers-Scotton 1997).

Borrowing is undoubtedly a common practice in North Africa, and even the speech of non-French speakers is influenced by French. In this case, the loan words should no longer be considered French since they lose their original phonological features when they are incorporated into local dialects of Arabic: they are assimilated into the phonology of the Arabic. Many common words in everyday use are French, although they have been 'Arabized': commissariat (police station), congi (leave, holiday), taubis (autobus, bus), for example. Code switching is different from borrowings in the sense that the French items used in Arabic preserve the pattern of the source language. Although this section focuses on the alternate use of Arabic and French, the same principle applies to borrowings and code switching between French and Berber.

For many educated people code-switching is a way of life. This has been documented in all three countries: Morrocco (e.g. Bentahila \& Davies 2002), Tunisia (e.g., Lawson \& Sachdev 2000), and Algeria (e.g., Queffélec \& Derradji 2002). Code-switching between dialectal Arabic and French is often unavoidable, as so many words and expressions related to modern life, in particular to the world of work, are simply not available in dialectal Arabic. With the spread of Arabization, these words should increasingly be available in MSA, and people will be aware of them, but at present, and certainly for older generations, French often springs to mind more readily.

The following section presents some instances of code-switching taken from Moroccan women's magazines written in French, and from conversations during phonein programmes on Radio Algiers (Chaîne 3). 
Although the use of French in magazines limits the audience to a relatively small part of the Moroccan population, it is important to note that the target audience is clearly Moroccan, not French. Whilst any French speaker would be able to read and understand most of the text, there is also a degree of code-switching, primarily into Moroccan Arabic, which makes the language peculiar to Morocco. Code-switching occurs in various ways, and for various reasons, but the most obvious use here is to create a sense of belonging for Moroccan readers. "In other words, context-specific terms are used for the purposes of reinforcing the shared beliefs and practices within a community and rekindling the spiritual bond of its members" (Skalli 2000: 221). The type of readers targeted will certainly code-switch on a regular basis in their daily lives, even if they do not recognize this, and thus the language of the magazines reflects the language of certain Moroccans, even if it is true that the majority of Moroccan women do not have access to this mixed code.

Use of this mixed code is more marked when the subject matter is culture-specific, for example on the subject of Ramadan. This is not a subject that would normally occur in a European magazine, but it is an unavoidable cultural reality in Morocco. On the cover of the November 2004 issue of Citadine, the fashion pages are referred to as 'le meilleur du beldi' ('country', here meaning traditional), whilst the Ramadan cookery feature in Femmes du Maroc is entitled Mon ftour à moi (the special name for the meal to break the fast). No explanation is given for either of these switches, since none would be needed for Moroccan readers, and there is no French word that expresses these concepts better.

Similarly, in the Algerian radio exchanges there is frequent use of Arabic terms which signal a religious reality for Algerian listeners that cannot be adequately expressed in French. As in the magazines, there is nothing in the Algerian radio exchanges to indicate that speakers are using a different language in the same utterance. Speakers communicate fluently without hesitation pauses, changes in sentence rhythm or intonation, for example: "on réussira b-rebbi" ('we'll succeed, God willing'), "je te souhaite beaucoup de chance in sha Allah" ('I wish you the best of luck, God willing') or, "il se porte bien maintenant, el Hamdoullah" ('he is feeling better now, thank God').

In the same issue of Citadine, a large number of Arabic words feature in an article referring to another important festival in the Islamic year, Aïd el Kebir. This festival celebrates the sacrifice of Abraham, and it is traditional for each family to sacrifice a lamb. The humorous title Moi, mon mari, le mouton et la bonne, mchat congi!! ('me, my husband and the maid who has gone on leave') will immediately be understood by all Moroccan readers, who will recognize the panic of the middle class housewife whose maid has gone to celebrate this festival in her village, leaving Lalla Fatéma ('madam') to cope with the arrangements concerning the haouli 'innocent' (lamb).

The use of Moroccan Arabic can contribute to a sense of community, a community of educated Moroccans who are all capable of speaking fluent French, but often find that the mot juste is in Darija (dialect). Examples of this can occur in interviews. Nassima Al Hor, journalist and television presenter, begins an interview (Citadine, 
February 2004) by saying she comes from a modest background but, hamdoullah ('thank God'), she and her siblings all went into higher education.

Similarly, although the conversations on the radio are held in French, the presenter feels the need to express his sense of membership with his Algerian listeners, and he begins the exchange with the Algerian greeting instead of bonsoir: "msa l-xir. Vous nous appelez d'où?" ('good evening. Where are you calling from?'). In the same way, a listener replies in French (bonsoir) but, by also using the Arabic greeting, expresses her sense of belonging to a larger community of Arabic listeners: "Bonsoir et msa-l-xir' à tous les gens qui nous écoutent" ('good evening and good evening to all the listeners').

The Moroccan women's magazines also appear to reflect the reality of life for modern working women who are trying to reconcile their modern working lives with Moroccan (Muslim) traditions. Being independent, educated women speak French but incorporate Arabic words to accentuate the Moroccan reality in which they live. This is particularly noticeable in humorous chronicles which appear in both Citadine and Femmes du Maroc. In April 2006, for example, Chama, the heroine in Citadine, addresses her would-be husband, who thinks too much of himself, as ould nass, literally 'son of people', but meaning from a respectable family, and then says lghaleb Allah 'Allah is the victor', in other words, it's out of your (or our) hands.

In November 2004, Femmes du Maroc introduces a modern couple who combine their busy Western lifestyle with a show of tradition. Abbas and Habiba (aka Olivette) are coping with the first day of Ramadan, which appears to be difficult in French: the special cakes and dishes are all named in Arabic (kaâb ghzal, chebbakiya, briouates, rghifates, mlaoui), while she refers to his mother as al oualida (slightly archaic term for mother). Olivette forgets to set the alarm for shour, the pre-fast meal, and is reminded by her husband of her 'Cartesian' education: "mais où avais-tu donc la tête? A moins qu’a la Mission française, on trouve ça beldi de se lever pour le shour?" (what were you thinking? At the French Mission school did they think that getting up to eat before fasting was too 'native'?). When Olivette's mother arrives in the evening, she feels ignored by her son-in-law and says: "A ouldi, tu manqueras pas un peu de souab par hasard?" ('son, have you forgotten how to be polite?'). As they wait for others to arrive to break the fast, Olivette worries that "il reste une minute pour la zouaga" (just a minute to go before the siren that lets people in towns know it is time to end the fast). As the men tuck into the meal, Olivette comments: "c'est quoi ces jiaânines, on dirait qu'ils ont jamais mangé de leur vie!" ('how hungry they are, it's as if they've never eaten before!'). As in previous examples, all the Arabic words used convey either a concept not used in French, or one that is different in Morocco.

According to Queffelec and Derradji, the use of such a large number of Arabic expressions in the French spoken in Algeria or in the Maghreb can be explained by an appropriation or "naturalisation" of the French language by the North African speakers and a need to give it national characteristics: Ils contribuent a donner à la langue 
française un aspect national et algérien, un refus de la réduire à une langue étrangère. ${ }^{7}$ (Queffelec \& Derradji 2002: PAGE NUMBERS). According to Bourhis, Lepicq, and Sachdev (2000), code switching is a form of intercultural communication which implies tolerance and promotion of linguistic pluralism while at the same time avoiding a focalisation on narrow identity issues raised by monolingual nationalist or global hegemonist:

L'alternance codique constitue une forme de communication interculturelle qui implique la tolérance et la valorisation du pluralisme linguistique tout en évitant les crispations identitaires des nationalistes unilingues et puristes ou des mondialistes hégémoniques. ${ }^{8}$

However, this is not always the case in the Maghreb and nowhere is this more apparent than in the educational sector.

\section{French language provision in schools}

To anyone from the English-speaking world, used to minimal teaching of other languages, it will appear that the French language is extensively taught in the state systems of the Maghreb. For increasing numbers of Maghrebian parents, however, provision is seen as quite inadequate, and increasingly those who can afford to do so prefer to send their children to private schools where bilingual Arabic-French education is the norm. In all three countries, there have been attempts in recent years to reform the education system, to improve standards across the board, in order to produce a well educated workforce. It is recognized that one of the major issues to be resolved is the language question, and in particular the mismatch between reduced provision of French in schools, and its continuing widespread use at university level. We will look in particular detail at how the situation has evolved in Morocco, and compare it with developments in Algeria.

Table 1 gives an overview of the situation across the region:

7. 'They contribute to making French a national language of Algeria, to the refusal to allow French to be reduced to a foreign language'.

8. 'Code switching is a form of intercultural communication which is tolerant and values linguistic pluralism, whilst avoiding the tensions over identity experienced by monolingual nationalists and language purists, or by those seeking world hegemony'. 
Table 1. Number of pupils/students learning French (Adapted from OIF 2007: 40)

\begin{tabular}{lccccr}
\hline Country & Population & $\begin{array}{c}\text { \% children in } \\
\text { school }\end{array}$ & $\begin{array}{c}\text { Primary } \\
\text { schools }\end{array}$ & $\begin{array}{c}\text { Secondary } \\
\text { schools }\end{array}$ & HE \\
\hline Algeria & $33,339,000$ & 72 & $3,000,000$ & $3,300,000$ & $1,500,000$ \\
Morocco & $30,700,000$ & 52 & $2,613,820$ & $2,040,850$ & 286,592 \\
Tunisia & $9,600,000$ & 74 & $1,836,626$ & $1,152,625$ & 160,000 \\
\hline
\end{tabular}

In Morocco, the provision of French became increasingly patchy during the 1970s and 1980 s, as its role in the state system changed gradually from being the language of instruction to that of foreign language. From as early as the 1960s, complaints were voiced about the drop in standards, and by the 1980s, it had become commonplace to say that standards had fallen. Many people firmly believed that Arabization and the concurrent loss of French in schools were to blame for this. Whilst this was doubtless part of the problem, there were and still are, other equally serious factors which are responsible, not least the fact that the education system changed rapidly from being an elite institution to being open to the masses. At Independence, only 269 Moroccans had the baccalauréat and only 3669 the Certificat détudes primaires ('primary school certificate') (Benzakour et al. 2000: 51), whereas today over $90 \%$ of young people receive at least a primary education. The Moroccan Ministry of Education claimed in 2004 that the proportion of children aged 6-11 in full-time education had gone up from $79 \%$ in $1999-2000$ to $92.2 \%$ in $2002-2003$, and the proportion of children aged $12-14$ had gone up from $58 \%$ to $68.8 \%$ in the same period. This national figure hides an enormous discrepancy between urban and rural areas, but this gap too seems to be closing: at primary level the increase was from $90 \%$ to $96.6 \%$ for urban areas, and $69.5 \%$ to $87.8 \%$ for rural areas, and for age $12-14$ figures went from $83.2 \%$ to $87.3 \%$ for urban areas, against $34.8 \%$ to $50 \%$ for rural areas (http://212.217.136/men/progres realises.asp). In a recent study (Marley 2004: 42), teachers at secondary schools expressed nostalgia for the excellent bilingual education they had received in the 1970s, claiming it produced better results than the current Arabized system. They failed to mention, however, the fact that they belonged to the small minority who had access to that education, and that the vast majority of Moroccans of that generation are not bilingual or even, in many cases, literate. The major cause of the perceived fall in standards must be the massive expansion with limited resources.

As far as French teaching itself is concerned, the fall in standards is relative: in absolute terms, the numbers of Moroccans who have learned French has risen dramatically since Independence. However, the way in which it has been taught has changed, both in theory and in practice. After Independence, French was no longer 
seen as a 'language of culture' and was to be taught purely for practical purposes. According to the Instructions Officielles of 1960, French teaching would involve:

L'étude de la langue considérée non pas comme un objet d'examen et d'étude, mais le maniement correct d'une langue usuelle, conçu essentiellement comme un instrument de communication. (cited in Chami 1987: 30) ${ }^{9}$

At the primary level, for example,

La langue française doit être enseignée en vue de son utilisation et non pour permettre la connaissance analytique de ses mécanismes. Elle doit être, à l’école primaire, non plus un objet d'étude mais un instrument d'expression. Elle doit être pratiquée et non démontée. ${ }^{10}$ (Instructions Officielles, cited in Chami 1987: 31)

The major objective of teaching French was to produce Moroccans who could speak French without a Moroccan accent; grammar was to be taught implicitly, and vocabulary and structures were to be functional and instrumental. The cultural context was to be realistic, related to the child's natural surroundings, and avoiding folkloric and 'exotic' images. The objectives at secondary level were similar, with a clear emphasis on the spoken language.

This insistence on the spoken language has serious consequences, according to Chami (1987: 9): although the major part of French teaching time is taken up with oral exercises, pupils are mainly tested in written form, so there is a mismatch between what they learn to do and what they are tested on, leading to poor results. Moreover, it is written French which is more likely to open doors to well paid jobs in Morocco, and which is needed for students going into higher education. There is thus a serious gap between what is taught in schools and what is needed in the outside world, caused by the gap between the official status of the French language and its real position in Moroccan society. Growing awareness of this mismatch was behind the change in direction proposed in the 2000 Charter for the Reform of the Education System.

This Charter, which covered the whole spectrum of the national education system, has a section on language teaching, with three major goals: "perfectionner l'enseignement et l'utilisation de la langue arabe, maîtriser les langues étrangères et souvrir sur le Tamazight"11 (Charte nationale d'éducation et de formation 2000: 50). Among other things, it proposes teaching science and technology in 'the most appropriate language'; at present this would mean French, although it can be assumed that in the future it

9. 'Language study in order to learn how to use the language correctly as a communication tool, not as a serious object of study or for passing exams'.

10. 'The French language is to be studied for practical reasons and not for academic purposes. In primary school, French should not be a subject to be studied but rather a tool for expression. It should be practised and not analyzed'.

11. 'To improve the teaching and use of Arabic, to master foreign languages and to initiate the teaching of Tamazight? 
could mean English. There is also a proposal to introduce the first foreign language very early (in the second year of primary school), and a second foreign language in the fifth year. This seems to herald a return to Arabic-French bilingualism in all but name. This move is seen as pragmatic by some, such as Berdouzi (2000: 21), who claims that to continue to teach sciences in Arabic would be disastrous for future generations of Moroccans. Others, however, such as Moatassime (2002: 144) believes that this "choix multilinguistique débridé [ ] risque de mener à l'impasse" ('choice of unbridled multilingualism is likely to lead to a dead end'), and feel disappointed that the Charter did not make more radical reforms in language provision, rather than returning to what he sees as the unrealistic objective of producing future generations of Moroccans bilingual in MSA and French.

At secondary school (collège), students have a further three years of compulsory education, during which French is taught for six hours per week (Arabic is also taught for six hours a week at this level). The MEN website sets out a list of objectives for these three years, but language acquisition does not feature on it. The same is true of the list of objectives for the final three years of secondary education, leading up to the baccalauréat. There is, however, a preamble to the section on the programme, which makes the following claim:

L' enseignement secondaire est une phase de spécialisation qui donne à l'élève la formation linguistique et les notions scientifiques et techniques nécessaires lui permettant d'accéder à l'enseignement supérieur ou à la formation professionnelle et débouchant par la suite à la vie active. ${ }^{12}$ (our emphasis)

Clearly, to achieve this end, French would have to be used extensively, at least in science and technology subjects, at this level. Moreover, despite the lack of detail on the website, important changes in the teaching of French at this level had already been implemented, even prior to the 2000 reform. In 1997, a new série option langue 'language track' was created in fourteen pilot schools, with the objective of producing students who were not only accomplished linguists, but who could also understand and master different registers and appreciate esthetic and cultural dimensions of literary works. Such an initiative underlines the fact that the Moroccan government is conscious of the need not only to improve the quality of French language teaching, but also to introduce a new cultural dimension, and enable students to operate on a higher level in French.

The situation in Algeria developed more rapidly and dramatically, due to the higher level of political and religious tension there. Arabization of the educational system was pursued with great haste in Algeria, and with scant regard for the needs of the children affected by it. For example, any student failing the last bilingual baccalauréat in

12. 'The level of specialization in secondary school should give students the language training and the scientific and technical knowledge needed to move into higher or further education and then into the world of work? 
1988 had no option but to retake it in Arabic the following year. At this stage, not only was French no longer used as a medium of instruction in state schools, but a decree forbade Algerian nationals from enrolling in the few remaining French lycées, making it difficult even for wealthy parents to ensure a bilingual education for their children.

This pro-Arabization, anti-French policy continued through the 1990s, culminating in the law of December 1996, which set the year 2000 as the date for eradicating French in education, even in higher education, and disciplines such as medicine, science and technology. However, since the election of Bouteflika in May 1999, the hard line on French seems to be softening slightly. The president himself has addressed audiences, both national and international, in French (L'Express 1999: 33), ignoring the 1996 law which makes it a punishable offence for politicians to use any language other than Arabic in their public speeches. Bouteflika has stressed the need to renew FrancoAlgerian cultural cooperation, and has challenged the pro-Arabization lobby by saying that Algeria did not have an irreversible position concerning the French language. Most importantly, as far as education is concerned, his government seems to have taken into account the various reports that blame the policy of Arabization for the failure of the Algerian education system to produce young people with the necessary skills for life in the modern world. It could equally be argued that there are multiple factors explaining the failure of the Algerian education system, not least the fact that the system is hopelessly overcrowded: high birth rates -20.07 per 1000 population in 2006 - mean that $63 \%$ of the population is under 30 years of age (ONS), and the number of teachers is quite inadequate to deal with this young population.

Whatever the reasons for the failure, the ministry of education has acknowledged it, and has followed Morocco's example, setting up a Commission nationale pour la refonte du système éducatif (May 2000) ('national committee for the reorganization of the education system') and initiating a thorough review of the education system. One of the reasons for the poor performance of Algerian schools generally was the widespread unrest throughout the 1990s and beyond. This had a significant impact on language teaching, with more than $50 \%$ of schools not having any foreign language teachers. Many teachers of French and English, particularly in rural areas, had abandoned their posts, after receiving threats from fundamentalists, fearing for their lives (Liberté 2001: 3 ). The Commission recognized the need for adequate language teaching, and recommended the introduction of French from the second year of primary education. It also recommended that French should be the first foreign language taught in secondary schools and that science and technology should be taught in French at university level (Liberté 2001: 4). Although Bouteflika’s government has implemented these recommendations, the pro-Arabization lobby appears to retain considerable influence, as indicated by recent comments made by Bouteflika concerning privately funded bilingual schools:

Je ne ferai pas de réforme au détriment de l'identité algérienne et de la langue arabe Nous avons perdu la langue arabe pendant cent trente deux ans et avons consenti 
beaucoup de sacrifices pour la récupérer. Aujourd'hui, il est tout à fait clair que je n'ai pas l'intention de jouer avec ça! ${ }^{13}$ (Le Monde, April 18, 2005: 6).

This continued uncertainty over the language issue underlines the reality that any changes tend to be dictated by political, rather than pedagogical, concerns. As Miliani has pointed out (2005: 138), "language policies and reforms have usually mirrored the struggle for power at the highest level". He suggests that this is particularly acute, and distressing, in the education system which has become "a living laboratory where language problems are posed and tentative answers are experimented with, but where no lasting solution is likely to be found because of the divided positions of decision-makers" (Miliani 2005: 134). In an interview to a newspaper (Le soir d'Algerie, August 19, 2007), Abderrazak Dourari, an Algerian linguist, said, 'Hélas, les étudiants ne maîtrisent aucune langue. Mon expérience dans le département de traduction me confirme cela. ${ }^{14}$

\section{The place of the Maghreb in the Francophone world}

Despite this type of pessimism from many within the education system, French clearly is widely taught and spoken in the Maghreb. Indeed, there are more 'real' Francophones in the Maghreb than in Western Europe: $23.6 \%$ of the population in the Maghreb, compared to $17.25 \%$ in Western Europe. The three countries of the Maghreb feature among the ten countries in the world with the most French speakers (État de la Francophonie dans le monde 2004-2006).

Not only is the Maghreb a significant French-speaking area, two of the countries are involved in the official Francophone body, the Organisation Internationale de la Francophonie. The OIF brings together 53 states and governments ayant le français en partage ('which share the French language'), for the most part former French colonies. Habib Bourguiba was one of the heads of state who first suggested the creation of such an organization in 1960, and thus, Tunisia has been a full member of the organization from the outset. Morocco has not played such a central role, but has been an associate member since 1981, and has attended the biannual summits since they began in 1986. Algeria, on the other hand, has never joined the organization, but in recent years has demonstrated a change of attitude towards it. Despite being the second largest Frenchspeaking country in terms of numbers of speakers (Bertoin 2005), Algeria resolutely refused involvement with the OIF until the Beirut summit of October 2002, when it attended as an 'observer'. It was assumed that this move heralded a return to the Francophone fold, but the foreign affairs minister, Abdelaziz Belkhadem, announced, prior

13. 'I will not undertake any reform which would be detrimental to Algerian identity or to the Arabic language... We lost the Arabic language for 132 years and made many sacrifices to get it back. Today, it is absolutely clear that I have no intention of risking losing it again!'

14. Alas, our students are not fluent in any language. My personal experience in the department of translation confirms this (F. Aitsiselmi). 
to the Burkina Fasso summit in 2004 that Algeria would not be changing its status as an observer, apparently yielding to the Islamist and pro-Arabization lobby. Bertoin (2005) comments:

Mais sans doute était-il alors trop tôt pour "consommer" ou même pour formaliser l'accord, compte tenu du contexte politique et religieux dans lequel s'inscrivait là-bas cette idylle naissante: islamistes et arabisants du sud de la Méditerranée mêlaient leurs protestations pour dénoncer les "soubassements idéologiques" encore présents dans la Francophonie, et le mariage - l’adhésion - fut repoussé une nouvelle fois, au grand regret des cinquante invités à la cérémonie. ${ }^{15}$

Agents of the OIF, notably the ACCT (Agence de coopération culturelle et technique) are very active in the Maghreb, particularly in Morocco, ensuring that French linguistic and cultural influence remain strong. The French government is also keen to maintain various types of link with the Maghreb, and so invests heavily in education and language provision, as well as remaining the first foreign trading partner.

To conclude our assessment of the current role and status of French, we will consider the domains in which French is still important.

\section{Domains where French is still important}

\subsection{Administration}

French remains a de facto working language in many departments, although the use of Arabic is becoming increasingly the norm. In Morocco and in Algeria, all official texts (constitution, laws, decrees, ministerial decrees) are produced in both Arabic and French. The Bulletin Officiel (the government publication listing new acts and laws, etc) is published in both Arabic and French. On the other hand, documents produced by the political parties are published only in Arabic (Benzakour et al. 2000: 86). One area of the administration where Arabization is fairly complete is the justice system; although it is still true that most judges and lawyers are French speakers, French is no longer an acceptable language in courts and all official legal documents must be in Arabic. The Ministry of Islamic Affairs is of course also completely arabized, but in many other areas of the administration, both national and regional, code-switching (Arabic-French) remains common among educated people, since many, if not most, were educated and trained in French, and often find it easier to express concepts in this

15. 'It is probably too early to confirm or even to formalize the agreement, given the political and religious context in which this emerging idyl has occurred. Islamic militants and the proArabization lobby south of the Mediterranean are joining forces to protest against the 'ideological bases' still present in the Francophone movement, and the marriage - joining - was put off once again, to the great regret of the fifty guests at the ceremony'. 
language. Official correspondence is in Arabic, but informally French is still acceptable and often used (Benzakour et al. 2000: 86-87)

\subsection{Education: Private sector and higher education}

As we have already seen, French continues to be an important part of the curriculum in state schools from an early stage, but is still just one subject among a number of others. In both the private sector, from nursery school onwards, and in much of higher and further education, French is used as a language of instruction. This is not what the policy-makers had expected: it had been assumed that Arabization would work its way through the education system including universities. However, the university sector has remained far from fully arabized, although in the humanities it has progressed further than in science subjects, which creates a real demand for bilingual ArabicFrench education at secondary and even primary level. In addition to the home-grown private sector, there is a growing network of French schools, particularly in Morocco, which claim to respond to a strong demand for bilingual education.

The network of French schools in Morocco is viewed by France as one of the most important elements in its programme of cultural exchange and cooperation in Morocco, lieux à la fois d'échanges, de formation et d'ouverture ('places for cultural exchange, training and opportunity'). For Jacques Sénécat, Director General of the Mission Laïque, 2000-2003, "Le Maroc est [..] une terre d’avenir pour la Mission Laïque". ('Morocco is a land of opportunity for the Secular Mission') (Lactualité de la Mission Laïque française et de l'OSUI 2003). Although the biggest schools are in Casablanca and Rabat, where the majority of the French community lives, they also have schools in eight other smaller towns, and of the 20,000 pupils registered (2004-5), 13,000 are Moroccan. There are 16 primary schools, 11 colleges (lower secondary schools) and five lycées (upper secondary schools) across the country.

There are also a small number of private Moroccan schools which are recognized by the French Ministry for Education, and must be inspected every year to ensure that they conform to French standards of educational practice. Morocco is at present the only Arab country where pupils at the secondary schools can take the Option Internationale du Baccalauréat, a fact which is attracting increasing numbers of students.

In contrast, Algeria has only one French educational establishment, the Lycée Alexandre Dumas in Algiers. All French schools were closed in the 1990s for security reasons, during the civil unrest and fundamentalist threats, and Alexandre Dumas was reopened by the Minister for Education in December 2002. At the start of the school year in 2004, there were 18 classes with a total of 600 pupils. The Algerian government does not officially try to promote the development of the French language, and has not encouraged the proliferation of French schools. However, in recent years, private 
schools offering French education have been increasing in numbers. According to Tselikas (2005):

le phénomène est massif: on recense plus de 2,000 écoles, jusque dans les coins les plus reculés. A tel point que le gouvernement s’apprête à légiférer dans ce domaine, sans remettre en question, du moins officiellement, la politique d'arabisation entreprise après l'indépendance. ${ }^{16}$

There could be as many as 80,000 Algerian schoolchildren in these private schools (Kourta 2004). Algerian parents know as well as Moroccans that an education in French can open the door to studying and working abroad, and are prepared to pay for it. France also began reopening its cultural centers in Algeria: Algiers in 2000, Annaba and Oran in 2002, Constantine and Tlemcen in 2005, thus enabling adults to attend French classes too.

Higher education, as mentioned earlier, continues to be only partially arabized, and increasingly private institutions are offering specialised higher and further education in French. In Morocco, French remains the language of instruction in science and technology, medicine and economics. The Guide de l'Etudiant Marocain (2002/2003) gives some idea of the extent to which higher education is dominated by French. Firstly, the Guide itself is published in French; the majority of institutions listed in it are private and operate in French - Moroccan universities (facultés) account for 19 pages of listings, right at the back, whereas other institutions account for over 200 pages. Among these, around 25 institutions, such as medical and veterinary schools, are public. This suggests that higher education in Morocco is primarily for wealthy bilinguals. Another interesting feature of this Guide is the fact that it devotes several pages at the beginning to information on how to go about applying for a grant to study overseas both from the Moroccan government and from a number of overseas governments, including France.

\subsection{The media}

French continued to be an important language of the press after Independence, for ideological, practical and technical reasons. As the colonial press gradually disappeared, however, the national French language press did not follow suit, but in fact continued to grow and develop. In 1981, for example, the French press in Morocco had a circulation of 130000 compared to only 62000 for the Arabic press. Throughout the 1990s, a variety of new publications appeared in French, both newspapers and

16. 'It is a massive phenomenon: there are more than 2,000 schools, even in the remotest areas. It has gotten to the point that the government is about to legislate on this issue, without questioning the policy of Arabization pursued since Independence - not officially, at any rate. 
magazines, and leisure and special interest magazines. This continued choice of French as a language of news is no accident; according to Benzakour et al. (2000: 94), French

n' est plus perçue comme la langue du colonisateur mais bien comme la langue $d u$ journaliste bilingue, s'adressant à un lectorat bilingue dont le français constitue l'une des composantes du patrimoine linguistique et culturel; c'est un idiome "revu et corrigé" à la dimension socioculturelle locale, que le journaliste marocain peut adapter à des fins expressives ou ludiques, pour mieux atteindre et toucher le public ciblé mais aussi pour rivaliser avec la presse étrangère, en particulier française. ${ }^{17}$

The Moroccan press also continues to publish in French as well as Arabic, and new titles continue to appear in French, although they are now well outnumbered by titles in Arabic. In 2000/ 2001, more than 70\% of new publications were in Arabic. The remaining 30\% were mainly in French, but English, Spanish and Tamazight were also used (Ben Ali 2002).

In the mid-1990s it was estimated that the French reading public and Arabic reading public in Morocco were of roughly the same size: about 100,000 each (cited in Benzakour et al. 2000: 96). These estimates are based on sales of the daily papers in each language, and it can probably be assumed that larger numbers actually read them. Nevertheless, the press is not widely read in any language: the Francophone press is only read by "un lectorat compétent, socialement influent mais réduit" ('a small readership, but highly influential in Moroccan society') (Benzakour et al. 2000: 97).

In Algeria, French continued to be the more popular choice among readers of daily papers into the 1990s: in 1993, there were 220,000 readers per day for the press in Arabic, compared to 625,000 for the French language press (Benrabah 1999: 271).

Radio in Algeria remains under state control, with coverage strongly in favor of state policies. However, the law now allows the licensing of private stations. State Algerian Radio (Radio-Algérienne) has three stations, one broadcasting in Arabic, one in Tamazight and one in French, and operates an international service broadcasting in Arabic, English, French, and Spanish (Algeria Press Overview 2001). Since 2004, it also operates two thematic stations and thirty regional FM stations.

The national radio company in Morocco, RTM (Radio Télévision Marocaine), broadcasts on two stations, one in Arabic and one in French. This use of French is intentional and sanctioned by the government (Charnet 1985). According to Ghazi (2001: 82), apart from the news and the occasional programme on a national or regional issue, it is hard to tell that this is a Moroccan, rather than a French, station.

17. 'Is no longer seen as the language of the colonizer, but as the language of the bilingual journalist, who addresses a bilingual audience, who see French as part of their linguistic and cultural heritage; it is a language which is 'tried and tested' in the local sociocultural context, and Moroccan journalists can adapt it for expressive and playful ends, as a better way of reaching their target audience, but also as a way of competing with the press from other countries, particularly France'. 
Another station widely listened to across the Maghreb, is Médi I (Méditerranée Internationale), a private station based in Tangiers. Linguistically it is unusual in that it frequently uses Arabic-French code-switching although it does also have time slots for each language. This use of language was justified by the station manager in an interview when it was set up in 1982: 'Nous avons opté pour le mélange tel que les Marocains le pratiquent, utilisant alternativement français et arabe. ${ }^{18}$ (quoted in Ghazi 2001: 83). According to its own website (www.medi1.com/medi1) it has 23 to 24 million listeners across the Maghreb, and this figure increases during the summer holiday period. One reason for the large audience is the fact that the station was set up, at the express wish of the late king, Hassan II, as a Franco-Moroccan venture, to prove his tolerance of uncensored news. It therefore has a reputation for broadcasting reliable national and international news.

Television in the Maghreb has been largely modelled on the French system, and in each case remained a state-controlled monopoly from the outset until the advent of satellite television in the mid 1980s. These national channels were all essentially instruments of state propaganda, poorly financed and ill-equipped to deal with the competition of the satellite age (Mostefaoui 1995: 15). France, on the other hand, saw the value of television as a means of maintaining a voice and influence, and invested heavily in coordinating broadcasting in this part of the world. The French see television as a vital tool for maintaining Francophonie in the Maghreb, as it is a means of gaining direct entry into people's homes. In societies where school systems are struggling, French television may be seen as an important source of information and cultural knowledge, and "comme une fenêtre ouverte sur la modernité et la connaissance" ('as a window opening onto modernity and knowledge') (Mostefaoui 1995: 251).

Despite the increasing availability of other channels, the state channels continue to attract audiences, and seek to influence them. Due to lack of finance, they tend to be highly dependent on foreign imports, which is a major reason for the continuing widespread presence of French.

In Algeria the state-run ENTV (Entreprise nationale de Télévision) is governed by the Ministry of Communication and Culture and is a public service. It did have a monopoly on terrestrial channels in Algeria, but the law allows private channels to operate since 1998.

The arrival of satellite television meant that Algerians had access to numerous Arab and French channels, and was seen as a threat to national identity by some, particularly fundamentalists, who attacked satellite television as an instrument of western influence or 'westoxification' (Ciment 1997: 142). In 1994, Algeria launched its own satellite channel, Canal Algérie, targeting the Algerian community in Europe, and aiming to provide a cultural link with Algeria. According to a survey by Institut Abassa in 2001, Canal Algérie is the sixth most popular channel in France, and has been

18. 'We opted for the kind of mixture that Moroccans actually use, alternating French and Arabic'. 
recognized as an important international Francophone channel. Since 2002, it has also been broadcast in Algiers as a terrestrial channel. In 2001, channel A3 was launched via the Arabsat satellite, targeting the Algerian community in Arab countries. A recent opinion poll conducted by Institut Abassa found that Algerians have a preference for Algerian channels but that they also watch 27 French-speaking channels and 24 Arabic-speaking ones (Iddir 2006).

In Morocco, the state channel, RTM (Radiodiffusion Télévision Marocaine) broadcasts mainly in Arabic, but also in French. News broadcasts are in Arabic, but once a day there is a ten minute bulletin in French, and one in Spanish. Since 1994, there has also been a short news summary in each of the three major varieties of Tamazight after the $1 \mathrm{pm}$ news. Although the majority of programming is in Arabic, French features regularly in a number of types of broadcasts. French films, documentaries and series are shown frequently, without dubbing or sub-titling, underlining the fact that French is seen as a natural part of the Moroccan linguistic landscape.

Since 1989, state television has had competition from 2M International. The French content on this channel was from the outset far higher than on RTM: originally 71\%, but reduced to 50\% in 1992 (Benzakour et al. 2000: 99). The news bulletins are in both French and Arabic. Ghazi (2001: 77) suggests that the continued and regular use of French on Moroccan national television is indicative of "la place qu'occupe la langue française et, par voie de conséquence, la culture française dans le bain linguistique et culturel marocain". ${ }^{19}$

\section{Conclusion}

This chapter has described the evolution of the sociolinguistic landscape of the Maghreb, focussing on the way in which French, despite being such a latecomer, has had a widespread and far-reaching impact. It is clear, and understandable, that French quickly became the language of prestige in a number of important domains during the colonial era. Less understandable, however, is the fact that French has not disappeared in the half century following Independence. Although the displaced elites of the Maghreb were quick to emulate the French in imposing a language policy, the Arabization process has not achieved the desired results and French retains an important linguistic influence in many significant domains.

Officially, French has no status in any of the three countries of the Maghreb, the only official language being Arabic. Nevertheless, it does enjoy a privileged status and

19. 'The place of the French language and therefore of French culture in the linguistic and cultural environment in Morocco'. 
is far from being just a foreign language. In Morocco, for example, the Instructions Officielles for 1987 underline that French has a special status:

il n'est ni une langue étrangère au sens strict du terme ni une langue officielle. Il a le statut de langue étrangère privilégiée ou première langue étrangère au Maroc ${ }^{20}$ (Benzakour et al. 2000: 85).

In Algeria:

Sans être la langue officielle, elle véhicule l'officialité, sans être la langue d'enseignement, elle reste une langue de transmission du savoir, sans être la langue d'identité, elle continue à façonner de différentes manières et par plusieurs canaux, l'imaginaire collectif $^{21}$ (Sebaa 2002: 9).

Although not recognized as a working language:

il est de notoriété publique que l'essentiel du travail dans les structures d'administration et de gestion centrale ou locale, s'effectue en langue française ${ }^{22}$ (Sebaa 2002: 9).

As this chapter has indicated, French is widely perceived as the language of social aspiration and mobility; it is also the means of access to a different - better - way of life, and the modern world generally. We have looked in some detail at the ways in which French continues to pervade the domains of education, administration and the media, but could equally have examined cultural production, in particular literature, since Maghrebian literature in French holds an important place in the Francophone literary canon. We have also not dwelt on the cultural interactions between the Maghreb and the Maghrebian diaspora in France, interactions which must increasingly be conducted in French, as the diaspora shifts from use of Arabic. For this reason, as well as the others stated, French is likely to continue to hold a special place in the sociolinguistic landscape of the Maghreb.

\section{Directions for future research}

As we have indicated, the role and status of French in North Africa has evolved in a way not foreseen by the language planners of the newly independent states some fifty years ago, and its continuing role as a prestige language means that there are still several

20. 'It is neither a foreign language strictly speaking, nor an official language. It has the status of privileged foreign language or first foreign language in Morocco.

21. 'Although not the official language, it conveys officialdom, although not the language of education, it conveys knowledge, although not the language of identity, it still shapes the collective imagination, in different ways and by different means'.

22. 'It is a well known fact that most of the work in the civil service and in central and local government, is conducted in French'. 
interesting areas of research to pursue. One is the issue of borrowing and code-switching, touched on briefly in this chapter. As in all multilingual societies, language contact is constantly changing, and there is a rich field of research to be pursued, in the ways in which code-switching between French and dialectal Arabic is developing in North Africa. These developments are affected by many factors, such as the democratization of education, increased contacts with France as well as with the Middle East, and the rapid development of texting and online communications. Linked to this would be the development of the media in French, both traditional print media and 'new' media, notably the internet. As we have noted here, since the 1990s, the use of French on national television channels has declined, and the Arabic language press is growing more than before, but French continues to be widely used in television, both in the public and private sector, and even now new titles in French appear in the kiosks. There is thus a wide field of research to be undertaken in the use of French in the media.

Another field of interest would be a comparative study of French among people living in North Africa and their relatives in the diaspora. It is increasingly the case that so-called second and third generation immigrants are monolingual French speakers, and yet strong links are often maintained with the 'home' country. Algeria has justified its use of French in satellite channels on the grounds that the target audience is Algerians and their descendants living in France; the existence of a large North African diaspora in France does contribute to the maintenance of French among families 'back home', and there are interesting studies to be conducted on language attitudes on both sides of the Mediterranean.

A third interesting direction would be to examine the impact of English: whilst French has held its own despite Arabization, there are growing indications that the next generations may find English a more useful language, given that it fulfils many of the roles currently fulfilled by French, and undoubtedly gives access to greater realms of cultural material, scientific research and other aspects of the modern world.

Finally, the effects of language planning in the post-colonial Maghreb is an area that has been widely researched, but primarily with a focus on the process of Arabization. In recent years, Morocco and Algeria have given official recognition to Berber languages, and all three countries seem to have implicitly recognized the value of retaining French in the education system. These developments open up new areas of research into how education and other areas of life in North Africa may be affected.

\section{References}

Assous, O. 1985. "Arabization and cultural conflicts". Unpublished doctoral dissertation, Northeastern University, Boston, Massachusetts.

Ben Ali, A. 2002. "Multiplication des titres de presse au Maroc: lére du pluralisme". Maroc Hebdo International 522: 13. 
Benrabah, M. 1999. Langue et pouvoir en Algérie: histoire d'un traumatisme linguistique. Paris: Séguier.

Benrabah, M. 2007a. "Language-in-education planning in Algeria: historical development and current issues". Language Policy 6: 225-252.

Benrabah, M. 2007b. "Language maintenance and spread: French in Algeria”. International Journal of Francophone Studies 10 (1): 193-215.

Bentahila, A. 1983. Language Attitudes Among Arabic-French Bilinguals in Morocco. Clevedon: Multilingual Matters.

Bentahila, A. and Davies, E. 2002. "Language mixing in rai music: localisation or globalisation?" Language and Communication 22: 187-207.

Benzakour, F., Gaadi, D., Queffélec, A. (eds). 2000. Le français au Maroc. Lexique et contacts de langues. Bruxelles: Editions Duculot.

Benzakour, F. 2004. "Le français en terre de contact ou l'histoire d'une identité qui se construit". In Penser la francophonie. Concepts, actions et outils linguistiques. Actes des premières journées scientifiques communes des réseaux de chercheurs concernant la langue contemporaine, M. Daff, X., Blanco and A. Queffélec (eds), 287-297.

Benzakour, F. 2007. "Langue française et langues locales en terre marocaine: rapports de force et reconstructions identitaires”. Hérodote: Revue de Géographie et de Géopolitique 126: 45-56.

Berdouzi, M. 2000. Rénover l'enseignement: de la charte aux actes. Rabat: Renouveau.

Bertoin, J. 2005. "Francophonie: Algériens, encore un effort!" Jeuneafrique.com ranctroffe0

Bickerton, D. 1981. Roots of Language. Ann Arbor, MI: Karoma.

Boukous, A. 1995. "La langue berbère: maintien et changement". International Journal of the Sociology of Language 112: 9-28.

Boukous, A. 1999. Dominance et différence: essai sur les enjeux symboliques au Maroc. Casablanca: Editions Le Fennec.

Bourhis R. Y., Lepicq, D. and Sachdev, I. 2000. "La psychologie sociale de la communication multilingue”. DiversCité Langues. Online. Vol. V. http://www.teluq.uquebec.ca/diverscite

Chami, M. 1987. Lenseignement du français au Maroc. Diagnostic des difficultés et implications didactiques. Casablanca: Imprimerie Najah el Jadida.

Cheddadi, A. 2003. Éducation et culture au Maroc. Casablanca: Éditions Le Fennec.

Diplomatie.gouv.fr.. 2007. Réunion du Haut Conseil Universitaire et de Recherche Franco-Algérien.erie 1015/cooperation culturelle scientifique technique 3994/index.html)

Dourari, A. 2007. L'Algérien ne maîtrise aucune langue. Le Soir d’Algérie.

Elbiad, M. 1991. "The role of some population sectors in the progress of Arabization in Morocco". International Journal of the Sociology of Language 87: 27-44.

Ganiage, J. 1982. Histoire contemporaine du Maghreb de 1830 à nos jours. Paris: Fayard.

Ghazi, A. 2001. Projet de réforme du système éducatif marocain. Pour une école citoyenne. Casablanca: L'Alternative.

Gosnell, J. 2002. The Politics of Frenchness in Colonial Algeria, 1930-1954. New York: University of Rochester Press.

Grandguillaume, G. 1983. Arabisation et politique linguistique au Maghreb. Paris: Maisonneuve et Larose.

Heristchi C. 2004. "The Islamist discourse of the FIS and the democratic experiment of Algeria". Democratization 11 (4):111-132.

Ibn Abd al-Hakam (1922). Futûh Misr, wa'l Maghrib wa'l Andalus [translated by C. Torrey]. Yale University Press: New Haven. 
Iddir N. 2006. "ENTV-Pénétration et audience des programmes télévisuels: la télévision nationale manque de punch". El Watan: 1.

Kadi, L. 2004. "La presse d'expression française en Algérie: vers un état des lieux". Revue d'Aménagement Linguistique 107: 133-144.

Kourta, D. 2004. "Ecoles privées en Algérie: plaidoyer pour le bilinguisme". El Watan http:// www.algerie-dz.com/article841.html

Lacoste, Y. 2007. "Enjeux politiques et géopolitiques de la langue française en Algérie". Hérodotes: Revue de Géographie et de Géopolitique 126 (3): 17-34.

Laroui, A. 1975. L'histoire du Maghreb. Paris: Petite Collection Maspéro.

Laroussi, F. 1996. "Introduction: pour un Maghreb pluriel". Linguistique et Anthropologie, Cahiers de Linguistique Sociale: 7-12.

Lawson, S. R. and Sachdev, I. 2000. "Codeswitching in Tunisia: attitudinal and behavioral dimensions. Journal of Pragmatics 32: 1343-1361.

L'Express. 1999. "La revanche de Bouteflika".

Liberté. 2001. "Refonte du système éducatif: le français à partir de la 2ème année fondamentale".

Mansouri, A. 1991. "Algeria between tradition and modernity: the question of language". Unpublished doctoral dissertation, State University of New York, Albany.

Marley, D. 2004. "Language attitudes in Morocco following recent changes in language policy". Language Policy 3: 25-46.

Miliani, M. 2005. "Language policy in Algeria: between convergence and diversity". In Transition and Development in Algeria: Economic, social and cultural challenges, M.A. Majumdar and M. Saad (eds), 131-143. Bristol, UK: Intellect.

Moatassime, A. 2001. Francophonie - Arabe: un dialogue est-il possible? Une interrogation prospective face aux enjeux de la mondialisation. Paris: L'Harmattan.

Mostefaoui, B. 1995. La télévision française au Maghreb. Structures, stratégies et enjeux. Paris: L'Harmattan.

Mouhssine, O. 1995. "Ambivalence du discours sur l'arabisation". International Journal of the Sociology of Language 112: 45-61.

Myers-Scotton, C. 1997. "Code-switching”. In The Handbook of Sociolinguistics, F. Coulmas (ed.), 217-237. Oxford: Blackwell.

Naylor, P. C. 2000. France and Algeria: a history of decolonisation and transformation. Gainesville, Fl: University Press of Florida.

OIF. 2007. "Organisation Internationale de la Francophonie". La Francophonie dans le Monde: 2006-2007. Paris: Nathan.

ONS, Office National des Statistiques, Algérie, Population et démographie. http://www.ons.dz/ them_sta.htm

Peyrouton, M. 1966. Histoire générale du Maghreb: Algérie-Maroc-Tunisie des origines à nos jours. Paris: Albin Michel.

Queffélec, A, Derradji, Y., Debov, V., Smaali-Dekdouk, D. Cherra-Bencheffra, Y. 2002. Le français en Algérie: lexique et dynamique des langues. Bruxelles. Duculot.

Riols,Y.M. 2004. "Les sept plaies du Moyen Orient”. L'Expansion.com http://www.lexpansion. com/economie/1-les-7-plaies-du-moyen-orient 22791.html

Roberts, H. 2003. The Battlefield 1988 - 2002: Studies in broken polity. London: Verso.

Sayahi, L. 2004. "Aqui todo el mudo hablaba español: History of the Spanish Language in Tangier”. The Journal of North African Studies 9 (1): 36-48.

Sebaa, R. 1999. "L’Algérie et la langue française. Un imaginaire linguistique en actes”. Prologues. Revue maghrébine du livre 17. Special issue: Langues et cultures au Maghreb. 
Seux, J. 1997. "L'enseignement au Maroc durant le Protectorat: un enseignement "adapte'"'. In Langue, école, identités, N. Marouf and C. Carpentier (eds), 97-146. Paris: L'Harmattan.

Skalli, L. H. 2000. "Articulating the local and the global: a case study in Moroccan women's magazines". Unpublished doctoral dissertation, Pennsylvania State University.

Stone, M. 1997. The Agony of Algeria. London: Hurst and Company.

Tselikas, E. 2005. "La saga des lycées français de là-bas". L'Express. http://www.lexpress.fr/info/ monde/dossier/francophonie/dossier.asp?ida $=432709$ 